\title{
David versus Goliath: Airbnb and the New York Hotel Industry
}

\author{
Richard McGowan \\ Boston College \\ John Mahon \\ University of Maine
}

\begin{abstract}
The last half-decade has seen a sharp increase in both the number and popularity of peer-to-peer firms, which set up markets that allow individuals to borrow or sell under-utilized assets without a third-party intermediary. Firms that fall under this moniker - Uber, Lyft, DogVacay, and Airbnb - collectively make up what is often known as the "sharing economy" or "access economy;" their success can largely be attributed to easier access to technology by both suppliers and demanders, allowing markets to be seamlessly entered/exited and transactions to be mediated at low costs. Our research focuses on market segmentation between peer-to-peer firms and more traditional firms, looking specifically at New York City [NYC] Airbnb units and high end NYC hotels. According to their website, Airbnb is a "community marketplace for people to list, discover, and book unique accommodations around the world - online or from a mobile phone or tablet," and has served over 60 millions guests in over 34,000 cities since its 2008 inception ${ }^{1}$. In short, Airbnb allows individuals to monetize extra space in their homes by leasing it out to travelers and other short-term renters ${ }^{2}$. While sharing economy firms in general have faced their share of backlash in many cities, Airbnb has encountered vehement opposition from the state government of New York [NY]. In October 2016, NY Governor Andrew Cuomo signed a bill that increased the maximum fine for short-term rentals in entire apartment buildings (Bensinger, 2016). Airbnb quickly filed a countersuit against the state, but settled soon after, agreeing to "crack down on individuals in New York City who rent out multiple homes, bowing to pressure from politicians and tenants' rights groups who say the company has worsened affordable housing issues in the city" (Benner, 2016). The company has also suggested it would collect taxes on certain units, but politicians suggest that this would only legitimize the otherwise illegal business (Benner, 2016). As of February 2017, Airbnb has launched a campaign to track hotels and hotel representatives who have argued that Airbnb should contribute more through hotel taxes and then switched their position. The ongoing report claims that The Hotel Association of New York has indeed changed their position ${ }^{3}$. This research seeks to engage this debate by qualifying if NYC Airbnb units actually share a market with traditional hotels and, if so, how serious a player they are in that market. Our analysis finds that although Airbnb's entry into the NYC short-term rental market has had a statistically significant effect on hotel revenue, occupancy, and average daily rate [ADR], but these effects are quite small.
\end{abstract}

\section{INTRODUCTION}

The last half-decade has seen a sharp increase in both the number and popularity of peer-topeer firms, which set up markets that allow individuals to borrow or sell under-utilized assets without a third-party intermediary. Firms that fall under this moniker - Uber, Lyft, DogVacay, and Airbnb - collectively make up what is often known as the "sharing economy" or "access

\footnotetext{
${ }^{1}$ See https://www.airbnb.com/about/about-us

2 See Figure 1 for a typical NYC Airbnb listing

${ }^{3}$ See https://www.airbnbcitizen.com/fiscal-flip-flops-big-hotels-and-taxes/
} 
economy;" their success can largely be attributed to easier access to technology by both suppliers and demanders, allowing markets to be seamlessly entered/exited and transactions to be mediated at low costs.

Our research focuses on market segmentation between peer-to-peer firms and more traditional firms, looking specifically at New York City [NYC] Airbnb units and high-end NYC hotels. According to their website, Airbnb is a "community marketplace for people to list, discover, and book unique accommodations around the world - online or from a mobile phone or tablet," and has served over 60 millions guests in over 34,000 cities since its 2008 inception ${ }^{4}$. In short, Airbnb allows individuals to monetize extra space in their homes by leasing it out to travelers and other short-term renters ${ }^{5}$.

While sharing economy firms in general have faced their share of backlash in many cities, Airbnb has encountered vehement opposition from the state government of New York [NY]. In October 2016, NY Governor Andrew Cuomo signed a bill that increased the maximum fine for short-term rentals in entire apartment buildings (Bensinger, 2016). Airbnb quickly filed a countersuit against the state, but settled soon after, agreeing to "crack down on individuals in New York City who rent out multiple homes, bowing to pressure from politicians and tenants' rights groups who say the company has worsened affordable housing issues in the city" (Benner, 2016). The company has also suggested it would collect taxes on certain units, but politicians suggest that this would only legitimize the otherwise illegal business (Benner, 2016). As of February 2017, Airbnb has launched a campaign to track hotels and hotel representatives who have argued that Airbnb should contribute more through hotel taxes and then switched their position. The ongoing report claims that The Hotel Association of New York has indeed changed their position ${ }^{6}$.

This research seeks to engage this debate by qualifying if NYC Airbnb units actually share a market with traditional hotels and, if so, how serious a player they are in that market. Our analysis finds that although Airbnb's entry into the NYC short-term rental market has had a statistically significant effect on hotel revenue, occupancy, and average daily rate [ADR], these effects are quite small.

\section{LITERATURE REVIEW}

Because of the recent rise in sharing economy firms and the lack of publically available data, there is not a substantial empirical literature on peer-to-peer firms and their effects on traditional firms. The literature specifically related to Airbnb is even sparser. The most relevant empirical work (Byers, Prosperio, and Zervas, 2014) employs a differences-indifferences analysis to find that Airbnb's entry into the Austin, Texas rental market resulted in an $8-10 \%$ decrease in hotel revenue. Additionally, the paper finds that hotels had less price control during periods of peak demand post-Airbnb entry. Airbnb has also commissioned a set of studies that, unsurprisingly, find their rise has had a positive economic impact, for example, by helping families of moderate income make ends meet ${ }^{7}$.

Other studies - conducted by both those with and without a vested interest in Airbnb's fate have been quite critical though. ShareBetter, a conglomerate of activists, elected officials, and neighbors in Los Angeles and NYC, claim that not only are $72 \%$ of Airbnb units in NYC illegal,

\footnotetext{
${ }^{4}$ See https://www.airbnb.com/about/about-us

${ }^{5}$ See Figure 1 for a typical NYC Airbnb listing

${ }^{6}$ See https://www.airbnbcitizen.com/fiscal-flip-flops-big-hotels-and-taxes/

${ }^{7}$ See https://www.airbnb.com/economic-impact/
} 
but also $36 \%$ of units are controlled by commercial operators and generated $37 \%$ of total Airbnb revenue ${ }^{8}$. Another paper (Edelman and Luca, 2014) finds that Airbnb implicitly facilitates racial discrimination, with non-black hosts being able to charge approximately $12 \%$ more than black hosts on equivalent properties.

We also engaged the growing literature on multi-sided markets and empirical studies on other sharing economy firms. Einav, Farronato, and Levin (2016) find that peer-to-peer markets can be advantageous because they often decrease search costs and lower barriers to entry/exit. As noted by Stigler (1962) in his seminal paper Information in the Labor Market, these search costs can often be quite steep and preventative. In the case of Craigslist, Kroft and Pope (2014) find these search cost reductions can be quite substantial. Similar results are noted with regard to the ride-sharing firm Uber (Jenks, 2015) and more generally for electronic markets (Bakos, 1997). This illustrates, theoretically, why Airbnb's rise has been so momentous: Hosts can enter and exit the market flexibly while consumers see decreases in search costs. Other work seeks to further establish the theory of multi-sided markets (Rochet \& Triole, 2003) and to understand the behavior of firms in these markets (Rysman, 2009) and how to regulate them (Carbó-Valverde, Charkravorti, \& Fernández, 2009).

Peer-to-peer firms may also have more far-reaching effects than lowering search costs and correcting market inefficiency. For example, Hall and Kreuger (2015) find that driving for Uber may smooth income over periods of unemployment. Airbnb could, in fact, exhibit a similar effect. Other work also suggests that ride sharing may have a positive environmental impact by reducing the number of cars on the road (Martin, Shaheen, \& Lidicker, 2010; Cervero, Golub, \& Nee, 2006-07).

Finally, we reviewed the literature on hotel demand. In attempting to forecast hotel demand in Ankara, Turkey, Yüksel (2007) finds demand to be driven by a variety of factors, including the global economy, the national economy and political climate, environment/ecological factors, pricing, and marketing. Slattery (2009) demonstrates a strong relationship between the magnitude of service businesses to GDP and hotel demand. External shocks also can have significant effects on hotel demand but research related to 9/11 and the Great Recession (Kosová \& Enz, 2012) suggests that hotels can recover quickly from these shocks. These considerations were factored into our choices for control variables in our analysis.

\section{DATA}

Our two main data sources are STR and Airdna. STR is a private firm that tracks global and regional hotel trends. Their data sets provide data on monthly hotel supply, demand, revenue, ADR, and occupancy in NYC from January 2006 - December 2016. Likewise, Airdna is a private Airbnb research analytics firm that provides supply, rental, and revenue data on NYC Airbnb units from August 2014 - December 2016. Control data includes national monthly average hourly earnings from the Federal Reserve Bank of St. Louis and regional airport passenger arrivals aggregated monthly from the NY/NJ Port Authority ${ }^{9}$.

We aggregate the data in two different ways. Primarily, our analysis breaks down NYC into ten different tracts as defined by STR. These tracts include East River - Queens/Brooklyn West,

\footnotetext{
8 See http://www.sharebetter.org/factsvsfiction/

${ }^{9}$ Regional airports include JFK International, LaGuardia, Stewart International, Teterboro, Newark Liberty International, and Atlantic City International. As a proud New Jersey resident it pains me to say that I assume those flying into Newark and Atlantic City are headed to NYC.
} 
Financial District, JFK/Jamaica, LaGuardia/Queens North, Midtown East, Midtown South, Midtown West/Times Square, New York City Area, Uptown, and Village/Soho/Tribeca ${ }^{10}$. These tracts are then aggregated for a citywide analysis. Our research looks at citywide trends as well as within tract trends and across tract trends.

\section{Airbnb Data}

As stated, the Airbnb data comes from Airdna, an independent Airbnb research analytics firm that "provides data and analytics to vacation rental entrepreneurs and investors"11. Their analytic reports have been used and trusted by Fox News, the Huffington Post, and the Wall Street Journal among others. Their data are acquired by webscraping the publically posted Airbnb listings and compiling every available Airbnb unit for that month, the days already rented, days available to rent, revenue, ADR, basic property characteristics, and location information.

We aggregate two Airbnb supplies: fixed and variable. The fixed supply is a count of the total Airbnb units listed for that month, irrespective of the number of days they have been rented. The variable supply aggregates the total number of days Airbnb units are rented for that specific month. Both supply metrics are aggregated citywide and within each tract.

Since the Airdna dataset only begins in August 2014, we assume both fixed and variable Airbnb supplies are 0 before this period. Given that the time of Airbnb's entrance into NYC is unclear and fixed Airbnb supply made up only $7.2 \%$ of total fixed supply of hotels and Airbnbs in August 2014, it was likely too small to matter.

\section{Hotel Data}

The hotel data comes from STR, a leader in tracking global hotel supply and demand. Their data are quite similar to the Airdna data - providing supply, demand, occupancy, ADR, and revenue information - except it is already aggregated to the tract level. We aggregate supply, demand, and revenue across tracts and average occupancy and ADR across tracts to get citywide totals.

\section{Supplementary Data}

We acquired supplementary data to control for other drivers of traditional hotel demand. Airport arrival data comes from the NY/NJ Port Authority and contains domestic, international, and commuter/regional monthly revenue passengers from January 2006 - December 2016. We also collected data on national unadjusted monthly average hourly earnings of production and nonsupervisory employees in the private sector from the Federal Reserve Bank of St. Louis. This includes non-supervisory salespersons, lawyers, doctors, drivers, accountants, and laborers among others ${ }^{12}$.

\section{DESCRIPTIVE FINDINGS}

The above-mentioned distinction between fixed and variable Airbnb supply is critical because sometimes a unit is listed but is only available to rent for a few days in a given month. This stands in contrast to traditional hotel rooms either being rented or available to rent nearly every day in a given period.

\footnotetext{
10 See Figure 2 for a visualization of the tracts

11 See https://www.airdna.co/about

12 See https://fred.stlouisfed.org/series/AHETPI for a complete list of those included in these data
} 
Though the fixed supply of Airbnb units has been growing steadily since 2009, Airbnb has made substantial inroads over the last two-and-a-half years, growing by $173.38 \%$ from August 2014 through December 2016. In that same period, traditional hotels have only seen growth of $10.67 \%$ in terms of fixed supply of rooms. Nevertheless, assuming market share is denoted by fixed supply, Airbnb has just 16.09\% of the market as of December 2016. Figures 3 and 4 show monthly Airbnb and hotel fixed supply growth, respectively, over the period from August 2014 through December 2016.

Airbnb fixed supply has seen not only citywide growth but also significant growth within each tract. Over the nearly two-and-a-half year period that my data tracks, Midtown South saw the smallest growth at $127.94 \%$. In general, the most substantial growth was seen outside of Manhattan with NYC Area, LaGuardia/Queens, and JFK/Jamaica growing by 218.99\%, $300.00 \%$, and $362.50 \%$, respectively ${ }^{13}$.

Airbnb variable supply ends up telling a similar story. Across the city, variable supply saw growth of $159.89 \%$ over the same two-and-a-half-year period. Additionally, within-tract variable supply growth was comparable to the fixed supply growth in the same period. Looking at market share through the lens of variable supply, Airbnb still has only $13.45 \%$ of the market as of December 2016.

Airbnb's market share seems to be even smaller if we look at it by way of total monthly room generated revenues. In December 2016, Airbnb revenue made up 5.59\% of the total hotelAirbnb revenues in NYC. In fact, looking at Figure 5, we can see that Airbnb's market share has not reached higher than $6.14 \%$.

\section{METHODOLOGY}

Our analysis looks at the effect of Airbnb's entry on traditional hotels across NYC using an ordinary least squares (OLS) regression model of two different forms. My baseline equation is of the following form:

$$
\mathrm{H}_{\mathrm{t}}=\beta_{0}+\beta_{1} \text { Fixed Airbnb Supply } \mathrm{t}+\sum_{\mathrm{i}=2}^{3} \beta_{\mathrm{i}} \mathrm{X}_{\mathrm{it}}+\beta_{4} \text { Month }_{\mathrm{t}}+\epsilon_{\mathrm{t}}
$$

The dependent variable, $H_{t}$, represents monthly hotel revenue, monthly hotel occupancy, or monthly hotel ADR, depending on the model. The independent variable of concern is monthly fixed Airbnb supply for all of $\mathrm{NYC}^{14}$. $X_{2 t}$ denotes my control for airport arrivals while $X_{3 t}$ is unadjusted monthly average hourly earnings of production and nonsupervisory employees. Month $_{t}$ controls for monthly fixed effects. We tried to add other controls to our model as suggested by the aforementioned work on hotel demand, including the national unemployment rate, the NYC unemployment rate, and NYC hotel supply, but this led to issues with multicollinearity. Also, when we attempted to separate airport arrivals into its domestic, international, and commuter/regional components, we found similar issues. Since much of the dependent variable is driven by the seasonality captured in $M o n t h_{t}$, this is not surprising. Along

\footnotetext{
${ }^{13}$ Comparing growth across tract is not completely fair because I am not controlling for the size of the tract based on either area or population. See Table 1 for the complete statistics.

14 We ran our analysis with Fixed and Variable Airbnb supply and the results were nearly identical. Henceforth, assume any reference to Airbnb supply is fixed supply unless otherwise specified.
} 
with NYC as a whole, we ran this model on fourteen different regions throughout the city as defined by STR and myself ${ }^{15}$.

For robustness, we then made a slight change to the baseline OLS equation by adding Tract $_{k}$, which controls for within-tract fixed effects. Again, these are the ten tracts as defined by STR.

$$
\mathrm{H}_{\mathrm{tk}}=\beta_{0}+\beta_{1} \text { Fixed Airbnb Supply } \mathrm{tk}+\sum_{\mathrm{i}=2}^{3} \beta_{\mathrm{i}} \mathrm{X}_{\mathrm{it}}+\beta_{4} \text { Month }_{\mathrm{t}}+\beta_{5} \text { Tract }_{\mathrm{k}}+\epsilon_{\mathrm{tk}}
$$

In either model a statistically significant negative coefficient on Fixed Airbnb Supply indicates that Airbnb's presence in NYC leads to decreased hotel revenue. An insignificant coefficient is interpreted as Fixed Airbnb Supply having no effect on hotel revenue ${ }^{16}$.

We then attempt to quantify economic significance by looking at elasticity. We calculate elasticity using the following formula:

$$
\frac{\mathrm{d}(\log (\mathrm{H}))}{\mathrm{d}(\log (\text { Fixed Airbnb Supply }))}=\frac{\text { Fixed Airbnb Supply }}{\mathrm{H}} \cdot \frac{\mathrm{dH}}{\mathrm{d}(\text { Fixed Airbnb Supply })}
$$

where $H$ is the value of the dependent variable and $d H / d\left(\right.$ Fixed Airbnb Supply) $=\beta_{1}$. All elasticities are calculated at the mean. Elasticity is interpreted as the percentage change in hotel revenue/occupancy/ADR that comes from a 1\% change in Airbnb supply.

\begin{abstract}
ANALYSIS
Our regression results for NYC as a whole are reported in Table 3. In all six models Airbnb's presence has a statistically significant negative effect on NYC hotels. Column 1 suggests that the addition of a single Airbnb unit - irrespective of the number of days it is available to rent - will lead to a $\$ 7910.37$ decrease in total hotel revenue. This estimate is significant at the 0.001 level. Airbnb supply is also highly significant in the models with hotel occupancy and hotel ADR as the dependent variable, respectively.
\end{abstract}

Once we control for within-tract fixed effects the magnitude on the Fixed Airbnb Supply coefficient becomes smaller in both regression 4 and regression 6 . In column 4 the magnitude of the t-statistic on Fixed Airbnb Supplytk becomes smaller by nearly 3.5 standard deviations. Given the striking changes from controlling for within-tract effects, we feel safe assuming that the coefficient on Fixed Airbnb Supply is actually biased negatively. In other words, Airbnb's effect on hotels is probably smaller than the model suggests.

Turning to the other control variables, we generally see the signs that we would expect. Regional airline passenger arrivals has a coefficient of 145.62 and is significant at the 0.001 level in all six columns. National average hourly earnings has a coefficient of 37000000 and is highly significant in columns 1 and 4 . Columns 3, 5, and 6 present confounding results for the national average hourly earnings coefficient though. It does not make sense that national average hourly earnings would generate higher hotel revenue while simultaneously leading to lower hotel occupancy. We consider the puzzling signs on these coefficients to be the result of

\footnotetext{
15 Regions include the ten tracts as defined by STR, Manhattan, Non-Manhattan, and two Manhattan/NonManhattan inter-regions. See notes 2 and 3 on Table 4 for more information.

16 We do not include a subscript on our coefficients if we are speaking about both the model that controls for within tract fixed effects and the one that does not.
} 
multicollinearity. The variance inflation factors for my various models confirm our suspicions. Because seasonality explains much of the data, we are not surprised to find some degree of collinearity among our control variables. Nevertheless, since they are not collinear with Fixed Airbnb Supply, we leave both in the model.

We omit the full regression results for the other fourteen groups of models for lack of necessity. Almost all of these models are microcosms of the results for NYC as a whole with Airbnb supply being significant at least at the 0.05 level ${ }^{17}$. Nevertheless, in Table 4 I present the elasticity for Airbnb supply at the mean for each model for the sake of completeness and to explore economic significance. Again, elasticity is interpreted as the percentage change in the dependent variable that comes from a 1\% change in Airbnb supply. The results in Table 4 make it clear that though Airbnb's effect on NYC hotels is statistically significant across the board, in terms of revenue, occupancy, and pricing the effect is not sizeable enough to be of concern.

This begs the question: why are hotels so concerned about Airbnb? Referring back to Table 1 and Table 2, Airbnb is growing rapidly. Every single NYC tract has at least doubled in fixed and variable Airbnb supply from August 2014 through December 2016. In addition, though Airbnb's share of hotel-Airbnb revenue is quite small, it has been steadily growing throughout the entire data sample. This suggests that the hotel industry's fears lay not in Airbnb's current market power but in the possibility of their future dominance.

Furthermore, though recent research (Kosová \& Enz, 2012) indicates that hotels can respond readily to demand shocks, the near frictionless entry into and exit from the Airbnb market suggests that Airbnb can respond even more quickly to sudden changes in demand. Table 5 provides a stark contrast between Airbnb and traditional hotel monthly changes in fixed supply. Though this does not directly address responses to changes in demand, the fact that Airbnb supply has increased by at least $16 \%$ in each of the last three Decembers while the largest increase for fixed supply of hotel rooms has been only $0.54 \%$ suggests that hotels are sluggish - and possibly unable - to respond to certain seasonal demand shocks. This could highlight another concern for NYC hotels.

Still, as of December 2016, the data suggests that Airbnb and traditional hotels may represent distinct markets. Though there has been no comprehensive research done on Airbnb guest demography, the general understanding is that Airbnb appeals to millennials more than it appeals to older travelers who are more comfortable with traditional hotels. Intuition also suggests that hotels would continue to appeal to businesses and business travelers who are already comfortable and have relationships with certain hotels.

This segmentation will likely not last though. Popular publications suggest that older demographics are beginning to use Airbnb more regularly and up to $30 \%$ of firms are now allowing employees to use Airbnb for business travel ${ }^{18}$. Airbnb has also shown interest in

\footnotetext{
17 To clarify, with hotel revenue as the dependent variable NYC Area, LaGuardia/Queens North, and JFK/Jamaica are insignificant; with hotel occupancy, LaGuardia/Queens North and JFK/Jamaica are insignificant; and with hotel ADR, only JFK/Jamaica is insignificant.

18 See https://techcrunch.com/2012/08/10/airbnb-is-really-awesome-and-international/ and https://www.fisherphillips.com/gig-employer/are-corporate-travel-programs-learning-tolove?utm_source=Mondaq\&utm_medium=syndication\&utm_campaign=View-Original
} 
attracting business travelers with the growth of AirbnbBusiness ${ }^{19}$. To list on AirbnbBusiness, a listing must have 5 stars on at least $60 \%$ of its ratings, a host must have a $90 \%$ response rate in 24 hours, hosts cannot cancel within 7 days of a check-in, the guest must be able to check in $24 / 7$, the space must be an entire home or apartment, and the listing must have business amenities $^{20}$.

Table 6 provides some support for the above-mentioned claims. This table shows Airbnb fixed supply growth from August 2014 through December 2015, where Airbnb units are separated into ADR quantiles. Quantile 1 has the smallest mean ADR, while quantile 4 has the largest ${ }^{21}$. As our other supply data suggests, we see large growth across all ADR quantiles. Nevertheless, the largest growth is in quantile 4, which contains Airbnb units with an ADR greater than \$210.71. Since it is unlikely that these are the units that younger patrons can afford, this suggests that Airbnb is indeed making substantial progress among older and wealthier clientele. Because my hotel data was already aggregated at the tract level when we received it, we cannot test for statistical and economic effects within each quantile, but this hints that the NYC hotel industry's fears may be well founded.

\section{CONCLUSION}

Since its inception, politicians in NY and NYC have made huge efforts to legislate and regulate Airbnb. If their concern is that Airbnb's rapid growth would cut into lucrative hotel taxes, they should not be alarmed. Our analysis suggests that although Airbnb is gaining market share month by month, the effect of its penetration in and around Manhattan has had minuscule effects on hotel revenue, occupancy, and ADR.

Nevertheless, NYC's Airbnb issue is a bit more complicated than these results suggest. Though hotels have not felt large-scale effects yet, it is realistic to expect that if Airbnb's growth continues it may take considerable market share away from traditional hotels.

From the non-hotel perspective, it would seem that Airbnb's growth could be quite beneficial though. Airbnb's flexible supply and nearly zero fixed costs allow demand to be met even during the most sudden ebbs and flows. Though it is difficult for hotels to compete with this flexibility in the short run, hotels and hotel managers have bounced back from sudden demand shocks readily in the past. That said, as noted by NY and NYC officials, Airbnb's rise does have some questionable side effects. These include alleged rising rents and safety concerns for New Yorkers who see a 'different neighbor' across the hall every week.

While our analysis provides robust evidence that NYC Airbnb has had a statistically significant but economically trivial effect on NYC hotel revenue, occupancy, and ADR, we believe there is room to expand upon this research in the future. As more data becomes available, it will be fascinating to see if NYC's hotel's fears play out or if the two markets maintain a degree of segmentation. This relies largely on how the demographics of Airbnb guests continue to change, a largely unexplored yet fertile area of investigation.

\footnotetext{
${ }^{19}$ See https://www.airbnb.com/business-travel and https://www.airbnb.com/press/news/airbnb-announcesnew-feature-that-allows-employees-to-book-business-travel-for-co-workers

${ }^{20}$ Amenities include WiFi, smoke \& CO detectors, iron, hairdryer, hangers, and shampoo. See https://www.airbnb.com/business-travel-ready for more information

${ }^{21}$ See notes 1-4 on Table 6 for exactly how the quantiles defined
} 


\section{References}

Bakos, J. Y. (1997, December). Reducing Buyer Search Costs: Implications for Electronic Marketplaces. Management Science, 43(12), 1676-92.

Benner, K. (2016, October 28). Airbnb Proposes Crackdown on New York City Hosts. New York Times, pp. B2.

Bensinger, G. (2016, November 22). Airbnb Settles NYC State Suit: Focusing on City. Wall Street Journal. Retrieved from http://www.wsj.com/articles/ airbnb-drops-new-york-state-suit-focusing-on-city-1479849933.

Byers, J. Proserpio, D., \& Zervas, G. (2016, November 18). The Rise of the Sharing Economy: Estimating the Impact of Airbnb on the Hotel Industry Boston U. School of Management Research Paper No. 2013-16. Available at SSRN: https://ssrn.com/abstract=2366898

Carbo-Valverde, S., Chakravorti, S., \& Rodriguez-Fernandez, F. (2009, November 19). Regulating Two-Sided Markets: An Empirical Investigation FRB of Chicago Working Paper No. 2009-11. Available at SSRN: https://ssrn.com/abstract=1511809

Ceravo, R., Golub, A., \& Nee, B. (2006-07). San Francisco City Carshare: Long-Term Travel-Demand and Car Ownership Impacts. University of California at Berkley Working Papers. Retrieved from http://iurd.berkeley.edu/wp/2006-07.pdf.

Edelman, B. G. \& Luca, M. (2014, January 10). Digital Discrimination: The Case of Airbnb.com. Harvard Business School NOM Unit Working Paper No. 14-054. Available at SSRN: https://ssrn.com/abstract=2377353.

Einav, L., Farronato C., \& Levin, J. (2016). Peer-to-Peer Markets. Annual Review of Economics, 8, 615-35. D0I: 10.1146/annurev-economics-080315-015334

Jenk, J. (2015, February). Theory Meets Practice in the Taxi Industry: Coase and Uber. Munich Personal RePEc Archive. 1 - 7. Retrieved from https://mpra.ub.uni-muenchen.de/63206/

Hall, J., \& Kreuger, A. (2015, January 22). An Analysis of the Labor Market for Uber's Driver-Partners in the United States. Princeton University Working Papers. Retrieved from https://s3.amazonaws.com/uberstatic/comms/PDF/ Uber_Driver-Partners_Hall_Kreuger_2015.pdf

Kroft, K., \& Pope, D. G. (2014). Does Online Search Crowd Out Traditional Search and Improve Matching Efficiency? Evidence from Craigslist. Journal of Labor Economics, 32(2), 259-303.

Martin, E., Shaheen, S. A., \& Lidicker J. (2010). Impact of Carsharing on Household Vehicle Holdings. Transportation Research Record: Journal of the Transportation Research Board, 2143(1), 150-158.

Rochet, J. C., \& Jean Tirole. (2003, June). Platform Competition in Two-Sided Markets. Journal of the European Economic Association, 1(4), 990-1029.

Rysman, M. (2009). The Economics of Two-Sided Markets. Journal of Economic Perspectives, 23(3), 125-43. D0I: 10.1257/jep.23.3.125.

Stigler, G. J. (1962, October). Part 2: Investment in Human Beings. Journal of Political Economy, 70(5), 94-105.

Yüksel, S. (2007, March). An integrated forecasting approach to hotel demand. Mathematical and Computer Modeling, 46, 1063-70. 
Figure 1: Example of a NYC Airbnb Listing

Overview Reviews The Host Location

Brownstone Studio

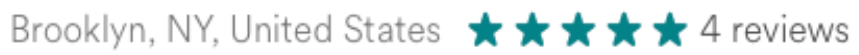

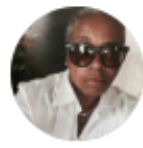

Michelle

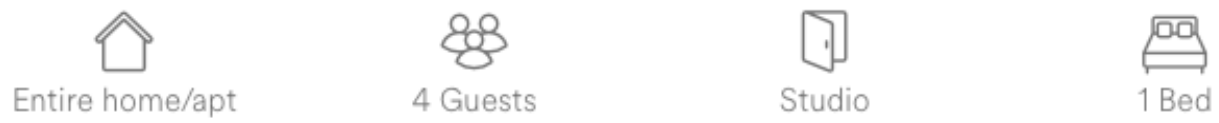

\section{About this listing}

This is a comfortable studio apartment with exposed brick that has a true city feeling. This studio has a newly renovate bathroom and kitchen with stain steel appliances. The space fits four and is centrally located on a Historic quiet street. This unit is loaded with cable and wifi. Just blocks away from public transportation $A$ and $G$ train lines. And minutes away from the bus route B25 B26 and the B44. Come and explore the charm of Bed-Stuy and all the Historic's. I love this neighborhood.

Contact host

Hosted by Michelle

US · Joined in February 2017

4 Reviews

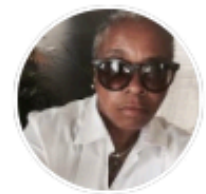

Contact host

Response rate: $99 \%$

Response time: within an hour 
Figure 2: Map of NYC Tracts as defined by STR
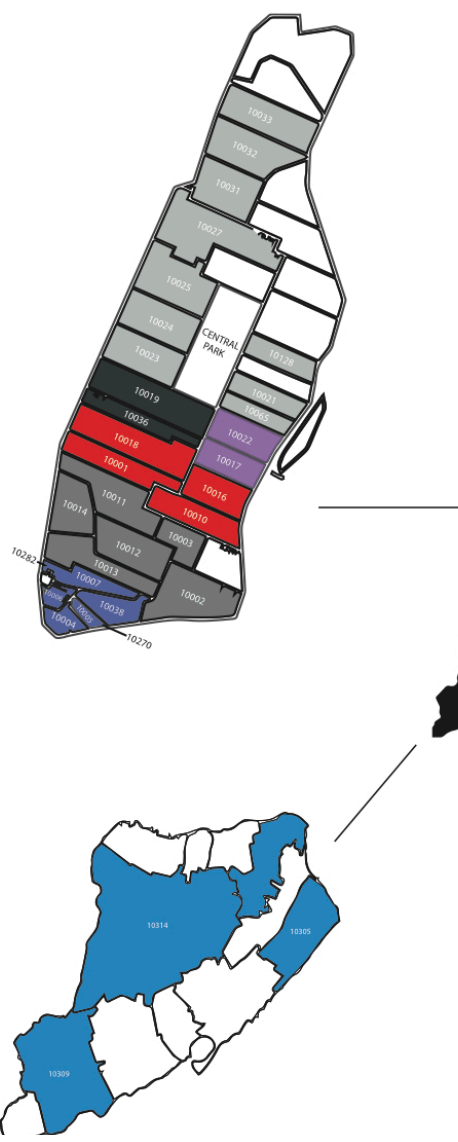

Financial District, NY 10004, 10005, 10006, 10007, 10038 10270,10282

New York City Area, NY

10301,10305, 10309, 10314, 10451, 10452 $10455,10458,10459,10460,10461,10463$ $10465,10466,10467,10469,10470,10471$ $10475,11203,11206,11207,11208,11209$ $11212,11213,11214,11216,11218,11219$ $11223,11232,11233,11235,11237$

Midtown West/Times Square 10019, 10036

\section{Uptown, NY}

$10021,10023,10024,10025,10027,10031$ $10032,10033,10065,10128$

\section{Midtown East, NY}

10017,10022
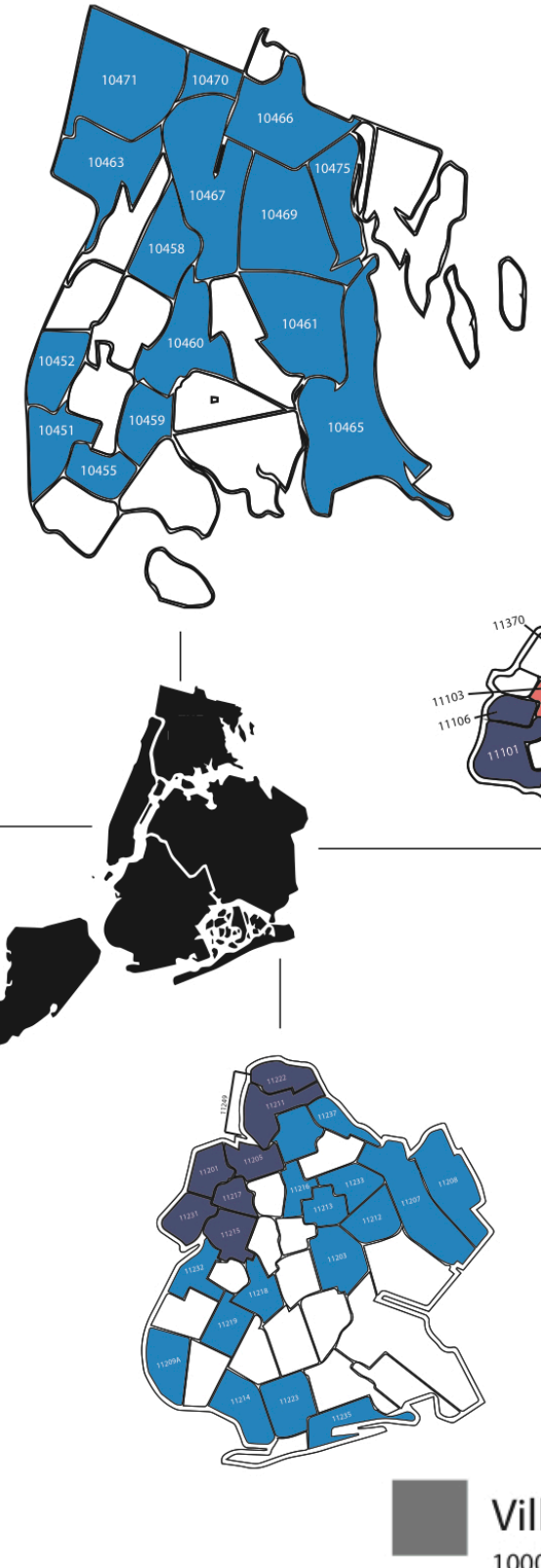

Village/ Soho/Tribeca

$10002,10003,10011,10012,10013,10014$

Midtown South

10001, 10010, 10016, 10018

JFK/ Jamaica, NY

$11414,11417,11420,11422,11428,11430$ $11432,11433,11434,11435,11436,11691$

La Gaurdia/ Queens North

11001, 11103, 11354, 11356, 11357, 11361 $11368,11369,11370,11373,11374,11377$ 11378,11426

East River- Queens/ Brooklyn West 11101, 11106, 11201, 11205, 11211, 11215 $11217,11222,11231,11249$ 
Figure 3: NYC Airbnb Fixed Supply Growth

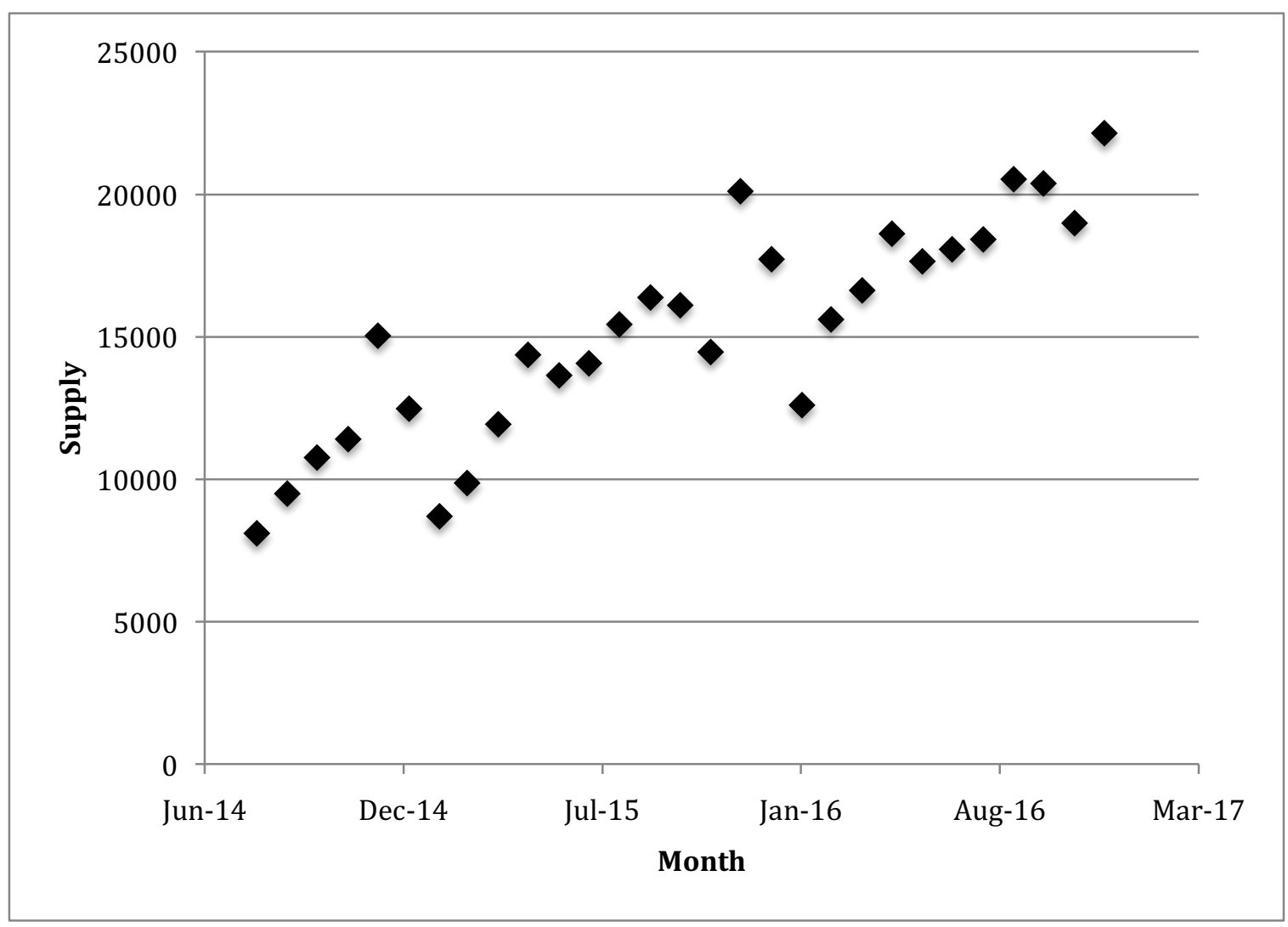

Figure 4: NYC Traditional Hotel Fixed Supply Growth

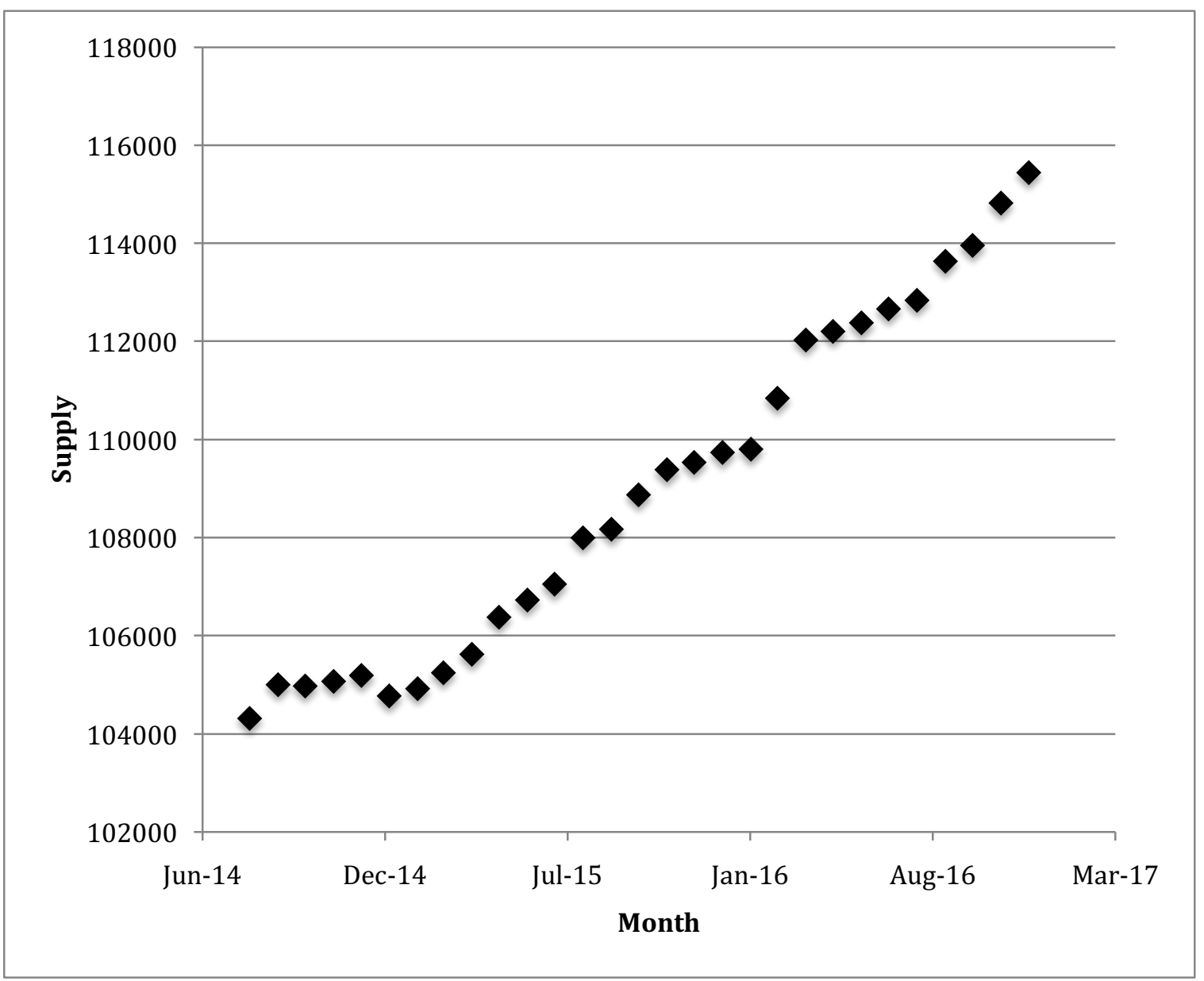


Figure 5: Airbnb's Total Revenue Share as a Percentage of Total Hotel-Airbnb Revenues

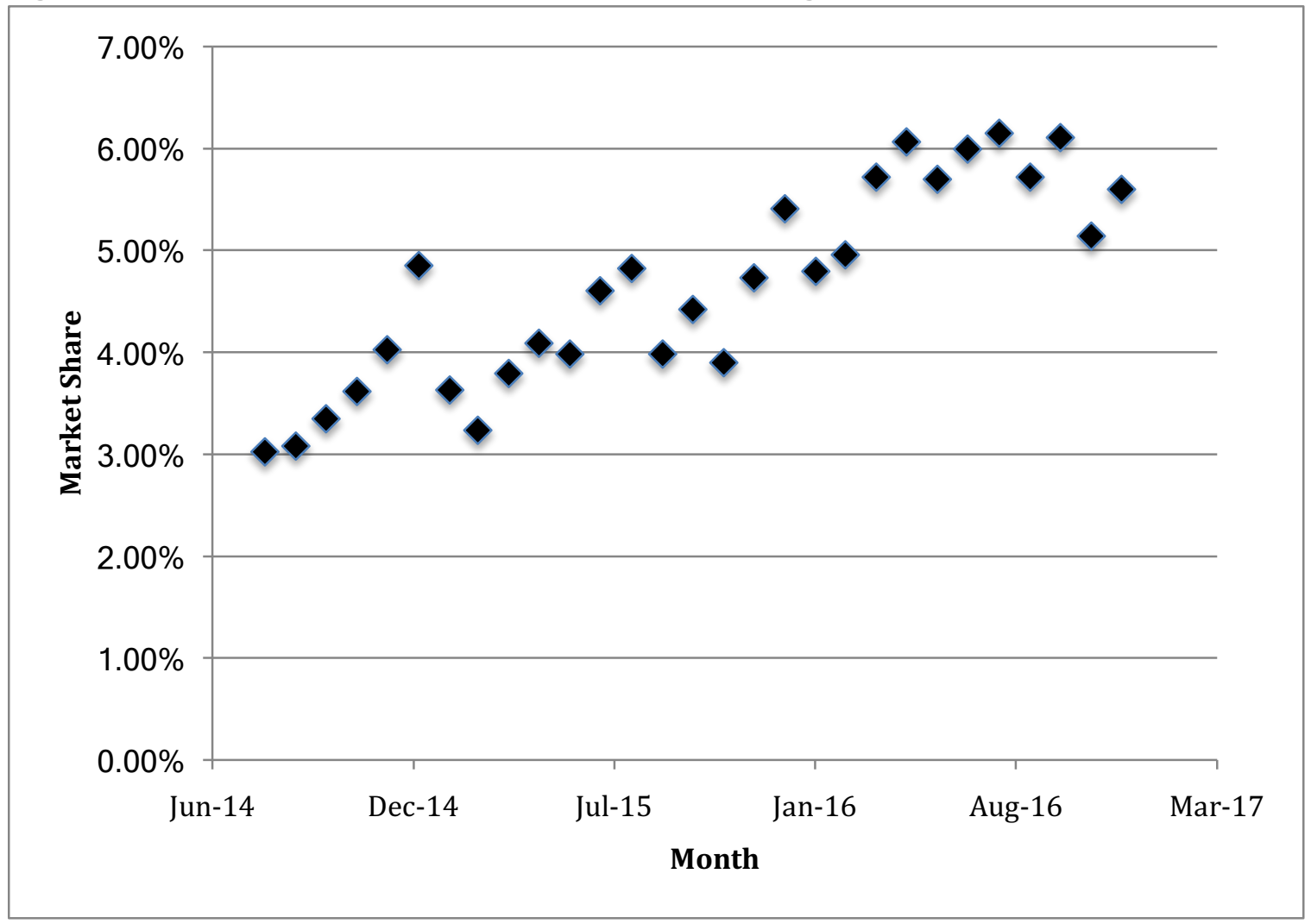

